\title{
Code Switching in Discussion Activities in English Class
}

\author{
Novita Kusumaning Tyas
}

Sekolah Tinggi Elektronika dan Komputer, Indonesia

Correspondence: Novita Kusumaning Tyas, Sekolah Tinggi Elektronika dan Komputer, Indonesia. e-mail: novitakusumaning@ stekom.ac.id

Submitted: January 03, 2020

DOI: $10.29408 /$ veles.v4i1.1797

Revised: February 27, 2020

Accepted: March 09, 2020

URL: http://dx.doi.org/10.29408/veles.v4i1.1797

\begin{abstract}
The purpose of the research is to identify types and to explain the function of code switching which are produced in discussion activities in English class. Descriptive analysis was used as the method of the study. The participants were twelve students of STEKOM that take English 3 class. The utterances produced by the students and lecturer in discussion activity become the data of study. The result showed the total number of code switching in discussion activities was 165 utterances. Based on grammatical classification, it was found 77 utterances or $46.67 \%$ for intersentential, 61 utterances or $36.97 \%$ for intra-sentential and 27 utterances or $16.36 \%$ for tagswitching. Based on contextual classification, it was found 106 utterances or $64.24 \%$ for situational and 59 utterances or $35.76 \%$ for metaphorical. The function of code switching often used by the students was to emphasis the meaning of utterances. It holds 45 utterances or $27.27 \%$ from all utterances. From this research, it can be concluded that code switching cannot be avoided in English teaching in STEKOM. It is because the students do not take English as their major so they lack of English vocabulary. In addition, code switching happened in order to make understandable meaning among them.
\end{abstract}

Keywords: code switching, discussion activity, student's presentation, bilingualisme

\section{Introduction}

Language plays important role in communication. By language, people can share information to other. Language also cannot be separated from culture. Indonesia is a country that has many cultures. It means that Indonesia has many languages which used as a tool of communication. So, Indonesia is known as bilingual country. As stated by Uriel Weinreich (1953) bilingualism is the practice of alternately using two languages. It means that to be a bilingual, a person who speaking two languages should master the two languages well. One of the form of bilingualism is code switching. Code switching is a widespread characteristic of bilingual speech. However, when talking to other bilinguals, people will probably use both languages. Thus, in bilingual conversations, they often switch form one language to another and 
frequently even within an utterance. Hamers and Blanc in Anastasia Deibert (2010) stated that code switching is one of the most common and original strategies used by bilingual speakers among themselves. In the beginning bilingualism and especially code switching were considered as "a sign of linguistic decay" (Apple Muysken 1987). It was stated that bilinguals are not able to acquire two languages properly and they often mix it ungrammatically. But nowadays some studies showed positive impact used code switching.

Code switching research has been conducted many years ago as from the foreign language teaching appear. The trend of code switching is now re-emerging with the phenomenon of "the language of South Jakartaes childen" (Bahasa Inggris anak Jakarta Selatan). They use mix language between Indonesian and English language in their communication. Dennis in CNN Indonesia (2018) said that this phenomenon is not a bad thing. He also stated that it has a positive impact. They recognized that English is important in their life. By using English Language in their communication it means that they have high level in their community. By mixing languages they began to be brave to speak using English although the vocabulary is still limited.

Research on code switching has been carried out since knowing that phenomena of code switching often happened in classroom activity. Gumperz in Marasigan (1983) said that "the fact that bilingualism and biculturalism have become accepted as major goals in schools is an important advance. But if these goals are to be achieved, at least some understanding of the nature of code alternation and its meaning in everyday interaction is required. It means that teaching English become more challenging in the modern era. Especially in this era that is called MEA (Masyarakat Ekonomi Asean) in English called with ASEAN Economic Community (AEC). English is needed in some aspect of life, not only in school but also in work life. So, an English teacher must be more creative in teaching English in order to make the student understanding the material given by the teacher.

The study of code switching in EFL classes has been conducted by some researcher. Indah Puspitawati (2018, p. 42-51), in her research revealed that the code switching was used by the teacher to facilitate students ${ }^{\text {ee }}$ learning. The reasons for using code switching to enable students to learn, to encourage them with low degree of L2 capability and to instruct effectively.. In her research also showed that the English teachers were aware of the use of code switching in teaching and learning process.

Nurhamidah, Fauziati and Supriyadi (2018) conducted their research about code switching. They examined the perspective of both teacher and students towards code switching and functions it in EFL classroom setting. From this study, in both perspective it was founded that the teacher used code switching to reduce the risk of misunderstood the material that the teacher given to the students. From students' side, they understood the material clearly. The functions of code switching that were founded in this study from the teacher perspective were as translation tool, as communication facilitator and as a checker students ${ }^{\text {ee }}$ comprehension. From students' perspective, the functions of code switching were as a tool of translation and to respond the other language. 
In Indonesian classroom setting, which English is a first foreign language, code- switching always happened in classroom interaction between teachers and students. It is naturally happen in teaching learning process. For example, in English class, the teacher explaining the materials using English to the students but then if the students do not understand it, the teacher directly translate it in Indonesian to make them understand. Because of that, code- switching is one of the phenomena which happened for the teacher and the students in the form of the interaction in the classroom. From the fact that this study will try to identify types of code- switching happened in the classroom and also tries to identify code switching function which appeared in classroom discussion.

\section{Method}

\subsection{Participants}

This research used twelve students of STEKOM Semarang as the samples. This research use random sampling technique to determine the samples. The twelve students came from the fifth semesters who take English 3 subject. In English 3 subject, students were asked to do presentation, so they mostly used their speaking skill in this class.

\subsection{Data Collection}

\subsubsection{Instrument of Collecting Data}

Based on Seaman in Eva Fachriyah (2017), instrument refers to devices used to collect data such as questionnaires, tests, structured interview schedules and checklist. The instruments that used in this research were observation, interview and recorded technique. The unit of analysis of the study in this research is the code-switching made by the students and lecturer in discussion activities in the classroom. The utterances were recorded from the non- English students in English 3 class when they were discussing in English class. The discussion activity in this study was presentation activity. Participants did presentation using English.

\subsubsection{Techniques for Collecting Data}

Techniques used for collecting the data as follows:

1. Observation technique

In the first step of collecting the data, the researcher observed the learning process in English class. The way students communicate during the class was the object of observation technique, especially languages that they used during teaching and learning process.

2. Interview technique

In this technique, the researcher interviewed the students who switch the language they used in the process of learning in English class.

3. Recorded technique

This technique was used to obtain the data of code switching that produced by the students in discussion activity. The data recorded was used to analyze code switching that happened in discussion activity. 


\subsection{Data Analysis}

In analyzing data, there were several steps that conducted by researcher. First, students' activity during presentation was recorded to obtain the data. Second, the conversation was transcribed. Third, code switching that occurred was classified by the researcher based on Poplack's (1980) and Bloom \& John.J.Gumperz's (1971) theory. Next step, the researcher described code switching that has been classified in the previous step.

\section{Results}

As has been explained in the previous chapter, cases of code- switching can be classified in accordance with two different classification; grammatical and contextual classification. According to Poplack (1980), the grammatical classification results in three types of codeswitching namely tag switching, inter- sentential and intra- sentential. Unlike the grammatical classification, which is based on the position of the different codes found in the utterances, the contextual classification is based on the reasons why people switch. Gumperz (1982) distinguished this classification into situational switching and metaphorical switching.

Table 1. Types of Code Switching

\begin{tabular}{|c|c|c|c|c|c|c|}
\hline \multirow[t]{2}{*}{ No } & \multicolumn{3}{|c|}{ Grammatical Classification } & \multicolumn{3}{|c|}{ Contextual Classification } \\
\hline & Type & Utterances & $(\%)$ & Type & Utterances & $(\%)$ \\
\hline 1 & Inter- sentential & 61 & 36.97 & Situational & 106 & 64.24 \\
\hline 2 & Intra- sentential & 77 & 46.67 & Metaphorical & 59 & 35.76 \\
\hline 3 & Tag switching & 27 & 16.36 & & & \\
\hline & Total & 165 & $100 \%$ & & 165 & $100 \%$ \\
\hline
\end{tabular}

The total numbers of code switching made by students were 165 utterances. The type of intra-sentential is the most type of code switching based on grammatical classification produced by students. It occurred 77 numbers from the total of utterances or $46.67 \%$ from all code switching. Based on contextual classification, the situational switching was the most produced by the students. There was $64.24 \%$ of utterances or 106 number of utterances from all code switching produced by the students.

The grammatical classification is based on where in the sentence or utterance the switching appears while contextual classification is based on the reasons why a bilingual switches (Bloom \& John.J.Gumperz: 1971).

Table 2. Function of Code Switching

\begin{tabular}{llll}
\hline No & Function & Utterance & $(\%)$ \\
\hline 1 & Emphasis & 45 & 27,27 \\
2 & Clarification & 39 & 23,63 \\
3 & Repetition & 27 & 16,36 \\
4 & Personalization & 1 & 0,60
\end{tabular}




\begin{tabular}{llll}
5 & Sense of Humor & 6 & 3.63 \\
6 & Group Identity & 6 & 3.63 \\
7 & Topic Shift & 11 & 6.67 \\
8 & Interjection & 5 & 3.03 \\
9 & Quotation & 8 & 4.85 \\
10 & Substitution & 17 & 10.30 \\
& Total & $\mathbf{1 6 5}$ & $\mathbf{1 0 0} \%$ \\
\hline
\end{tabular}

From the table above, it can be concluded that the most function of code switching produced by the students was emphasis. It occurred $27.27 \%$ or 45 utterances from all code switching. The least number of function was produced by the students was $0.60 \%$ of code switching as personalization.

\section{Discussion}

Based on the finding, the researcher found that the students and the lecturer most switch their utterances during the presentation activity. As stated in Anastasia Deibert (2018), those bilingual speakers that speak two languages usually code switching when speaking to other bilingual. Types of code switching that occurred most that based on grammatical classification was intra sentential that produced $46.67 \%$ from all code switching. As stated by Poplack (2002), intra sentential occurs within a clause or sentence boundary. It means that intra sentential code switching happens by inserted word, clause, and phrase in a base of a language.

Here is example of intra sentential that found in this research.

Lecturer : Is there any question for him?

Student : My name is Woro Sasmito, I want ask you. What is the definition of IP address? Apa definisi dari IP address?

The data above is taken from one of student's presentation. The code switching was produced by the student who asked question. He code switched the sentence "What is the definition of IP address?" to "Apa definisi dari IP address".

From the example of code switching above, it also shows that code switching was produced by the student has an emphasis function. Macaro (1997, p. 68) in Eva Fachriyah (2017) says "important messages can be reinforced or emphasized when they are transmitted in the L1". In the example above, the student wanted to give more specific about his question. He switched the question into Indonesian to make understandable meaning.

The second type of code switching based on grammatical classification that produced by students was inter-sentential. It produced 61 utterances or $36.79 \%$ of all utterances. Romaine in Usman Kasim (2019) stated that inter-sentential switching occurs at a clause or sentence boundary where each clause or sentence is in a different language. Example from the data is shown below. 
Presenter : "Next is tipe terakhir from computer network topology". "Last type is topology star". "In this topology there is centralized control called a hub or switch."

The sentences above was produced by the presenter when he presented his material. In the data above, he explained about the last type of network topology. In his sentence he inserted "tipe terakhir". In English means "last type". It belongs to inter-sentential because it happened between English words.

Tag Switching becomes the least switching that produced by the students. It occured 27 utterances or $16.36 \%$ of all utterances. McArthur (1998) defined that tag switching, in which tags and certain set phrases in one language are inserted into an utterance otherwise in another. For example, in the classroom " $Y a$, who can answer the question raise your hand". The word "ya" belongs to tag switching, it means yes. Example from the data is shown below.

Presenter : "Last, centralized control hub became a critical element as it gets big load."

"Nah, that is the type of computer network topology".

The sentence above was produced by the presenter when he explained the material. The word "Nah" appear in the sentence. It belongs to tag switching because it is inserted into the sentence. The word "Nah" means like well. So, the sentence "Nah, that is the type of computer network topology" should be "Well, that is the type of computer network topology".

Another types of code switching occured in this research are based on contextual classification. There was $64.24 \%$ of code switching that belongs to situational code switching.. Wardhaugh (1998) stated that "situational code switching occurs when the language used change according to the situation in which the conversant find themselves; they speak one language in a change of interlocutor, setting of topic". It means that this changing is based on the situational change from the conversation without changing the topic for example the entry of the other person in a conversation. Example of situational code switching from the data is shown below.

Presenter : “ACD FotoSlate is quick, easy, and very flexible software for creating printed photo layouts, calender, CD covers and cards."

"Jadi software ini mempermudah mencetak foto dengan berbagai macam ukuran, mencetak foto dengan berbagai macam ukuran, mencetak cover CD, kalender, kartu”.

The data above taken from student's presentation. The sentence "Jadi software ini mempermudah mencetak foto dengan berbagai macam ukuran, mencetak foto dengan berbagai macam ukuran, mencetak cover CD, kalender, kartu" belongs to situational switching. As stated in Steve Nicolle (2013) situational code switching occured due to a change of situational factors during a conversation. In addition, Wardaugh (in Ronnie Hendrik Riyanto: 2010) said that the changes happen for the whole part of one's speech in one context. In this example, the students switched the sentence to emphasize the meaning of the sentence. He switched the sentence without changing the topic of the sentence. The sentence "Jadi software ini mempermudah mencetak cover CD, kalender, kartu" is the Indonesian meaning of the sentence before. 
It was found 59 utterances or $35,76 \%$ code switching in this research that belongs to metaphorical switching. Mc.Cormick (1994:581) stated that methaporic code switching happens "in a whole conversation, each within one role relationship". It means that in this type of switching, the role of relationship between the speakers in the conversation may change. Example of metaphorical code switching from the data is shown below.

Presenter : "First, select an image that is easy to edit. Then save image in the computer and manipulation then I will do is "remove head"!! . Saya akan menghilangkan gambar kepala ini”.

Audience : "Wah, kriminal ki".

From the example above the sentence that belongs to metaphorical switching is "Wah, kriminal ki". This conversation occured between the presenter and the audience. The presenter explained the theory about the topic and applied in the program as well.

From students' presentation, it showed that there are some functions of code switching produced by the presenter, the students as audience and also the lecturer during the presentation activities. The most function used is emphasis. It occurred $27.27 \%$ from all utterances. Malik in Choy Wai Fong (2012) states that this emphasizes to make sure that listener knows what to highlight and focus on in situation such as an argument. It means that when code switching happened it is not always because of lack of vocabulary but because the students want to emphasize one thing to other.

The second function of code switching that occured in this research is clarification. It occured 39 utterances or $23.63 \%$ from all code switching. Romaine (1989) stated that this code switching occurs when a speaker want to specify what he or she talking about. To clarify means that the speaker resolves any ambiguity and averts misunderstanding on incomplete understanding. In addition, Eva Fachriyah (2017) stated that the learners feel the need to transfer the code switching into their native language for clarification of their previous converses in English.

Repetition become the next function of code switching that occured in this research. It happened 27 utterances or $16.36 \%$ from all code switching. Mattsson and Burenhult (1999) revealed that the importance of repetition in code switching is to emphasiz the message to be delivered following a quotation. The example of repetition function in this research conducted by the student as presenter. When he conveyed his presentation, he switched the sentence into Indonesian. The sentence is "Kalau installnya di laptop, maka diperlukan adaptor". The sentence means "If you will install in your laptop, you need an adaptor". He switched the sentence to make the sentence more understandable. As stated by Brice (2000) that repetition in code switching is to check understanding.

The fourth function of code switching that occured in this research is substitution. It is found 17 utterances or $10.30 \%$ from all code switching in this research. The main function of substitution is to give more information and further identify the noun. Topic shift become the fifth function fo code switching in this research. It is found 11 utterances or $6.67 \%$ from all code 
switching. Quotation code switching in this research occured 4.85\% from all code switching or 8 utterances. Interjection, sense of humor, group of identity and personalization become the rest of function of code switching that occured in this research.

\section{Conclusion}

The conclusion of the research is taken in accordance with the result of the data analysis in the previous chapter. In the previous chapter, the writer had analyzed the finding data of code switching. It is about the type, the function and also the realization of code switching which occurred in the discussion activities in English class. Based on the analysis in the previous chapter, the writes found out the type of code switching which mostly occurred in English class. The result shows that $46.67 \%$ of utterance in discussion activities is intra-sentential. It is based on grammatical classification. The other type, there is $64.24 \%$ of utterances is situational switching. It is based on contextual classification. Besides the types, the writer also found the function of code switching which mostly occurred in English class. The result shows that 27, 27 $\%$ of function of code switching is emphasis. The lowest of function was produced by the students was $0,60 \%$ is code switching as personalization.

\section{References}

Appel, R \& Mysken P. (1987). Language contact and bilingualism. London: Edward Arnold.

Bloom, J.P. \& J.J. Gumperz. (1972). Social Meaning in Linguitic Structure. Cambridge: Cambridge University Press.

Brice, A. (2000). Code switching and code mixing in the ESL classroom: A study of pragmatic and syntactiv features. Advances in Speech Language Pathology. Journal of the Speech Pathology Association of Australia, 2(1), 19-28.

CNN Indonesia, Tim. (2018, September 19). Fenomena Campur Aduk 'Bahasa Anak Jaksel'.

Retrieved March 21, 2019, from https:/www.cnnindonesia.com/gaya hidup/20180919154522-282-331461/fenomena-campur-aduk-bahasa-anak-jaksel.

Deibert, Anastasia. (2010). Code Switching in Bilingual Communication. Retrieved from grin. (ATT 26643)

Fachriyah, Eva. (2017). The Function of Code Switching in an English Classroom. Studies in English Language and Education, 4(2), 148-156.

Fong, Choy Wai. (2011). Function and reasons for code switching on facebook by bilingual undegraduate. The JatCall Journal, 4(3), 102- 105.

Gumperz, J.J. (1982). Discourse strategies. Cambridge: Cambrige University Press.

Hudson, R.A. (1996). Sociolinguistics (2nd ed). Cambridge: Cambridge University Press.

Kasim, Usman, Yunisrina Qismullah Yusuf and Sri Rahayu Jumiati Ningsih. (2019). The types and functions of code switching in a thesis defense examination. Journal of English Education, Literature and Culture, 4(2), 101-118.

Macaro, E. (1997). Target language, collaborative learning and autonomy. Clevedon: Multilingual Matters. 
Marasigan,Elizabeth. (1983). Code- Switching and Code Mixing in Multilingual Societies. Singapore: Singapore University Press.

Mattsson, A.,\& Burenhult, N. (1999). Code switching in second language teaching of French. Lund University, Department of Linguistics, Working Papers 47, 59- 72. Retrieved December 28th, 2019 from http://portal.research.lu.se/ws/files/6233889/624446.pdf.

McArthur, T. (1998). Concise oxford companion to the English language. Oxford: Oxford University Press.

Poplack, S. (1988). Contrasting patterns of code switching in two communities. In. M. Heller (Ed.), Code switching: Anthropological and Sociolinguistic Perspectives (pp.215-244). Berlin: Mouton de Gruyer.

Puspitawati, Indah. (2018). Teachers ${ }^{\text {ee }}$ Use of Code Switching in EFL Classroom and Its Functions. Journal of Foreign Language Teaching and Learning 3(1), 42-51.

Romaine, S. (1995). Bilingualism. Oxford: Basil Blackwell Ltd.

Wardhaugh, Ronald.(1976). The Context of Language. Massachusetts: Newbury House Ronald. Wardaugh, R. (1998) . An Introduction to Sociolinguistics. New York: Brasil Blackwell. Weinreich, Uriel. (1953). Languages in Contact. The Hague-New York: Mouton. 